\title{
College Students' English Listening Ability Training Strategies Based on the Angle of Student after Enrollment Expansion
}

\author{
Li Tongqi \\ School of Foreign Languages and Culture, Xihua University, Chengdu Sichuan 610039, China
}

Keywords: Students angle; Enrollment expansion of colleges and universities; English listening; Ability training

\begin{abstract}
English is one of the important courses in university study, and listening, speaking, reading and writing are the foundation of English study and application. Listening is an important English communication ability, which can directly reflect students' actual language foundation, and plays an important role for college students to learn more English and their future development. But with the enrollment expansion of colleges and universities, there are greater difficulties in English listening ability cultivation of college students, which makes slow improvement in students' listening ability and affects the improvement of students' comprehensive English ability. Based on the enrollment expansion of colleges and universities, this paper analyzes the cultivation problems in college students' English listening comprehension, and how to improve college students' English listening ability effectively from the perspective of students.
\end{abstract}

\section{Introduction}

In the process of learning English, listening, speaking, reading, writing, vocabulary, grammar and so on are all must knowledge of English to master. They are the parts of English comprehensive ability training. In daily English study, there is a need to learn and practice in many ways to improve the English level. English listening is a central part to improve the integrated communication ability of your English because when the listening ability is on a higher level, the cultivation of relevant abilities such as reading, writing, and so on will become more simple. In English application, listening ability can directly affect students' communicative level, but English listening ability has been of greater difficulty. As the result of college expansion in Suzhou and Zhejiang, the number of students increased, while the corresponding teaching did not achieve the desired effect, so a lot of college students' English learning ability decreased. This makes the cultivation of English listening ability harder. Numerous scholars' and professionals' attentions are on the cultivation of college students' English listening ability. Reasons for low English proficiency are analyzed from various perspectives in detail, and some training strategies are put forward. Combining with the writer's own experience, he thinks that to promote college students' listening ability, college students should begin to improve themselves, and then they can play a better effect. 


\section{Set up correct learning attitude}

Affected by enrollment expansion of colleges and universities, the number of students is a lot more than the original. However, the teachers' teaching experience is limited, who cannot completely pay attention to each student. English listening learning dynamics cannot relax and need to insist for a long time, and each student should have a correct learning attitude. English listening ability can be summarized as a kind of English communicative competence which is gradually cultivated by English speakers in the long-term language application practice. And the cultivation of listening ability is to achieve certain English communicative level, for relevant listening practice, and continuously consolidate and update the students' listening knowledge and ability in the process. But this is not the ability to ascend overnight, and it needs long persistence and practice to be gradually formed. Based on correct learning attitude, students need to establish clear learning objectives in order to better improve their ability of English listening, get to know their current levels, and according to the current ability and level, make corresponding practice. Straight out what knowledge is the foundation and which is the outspread with clear priorities; Set goals in the process at the same time and regularly test to verify if the corresponding goal is achieved.

In addition, students should have objective knowledge about the energy to cultivate English listening ability, which mainly includes two aspects of contents: one is that students must have clear understanding that English listening practice has to be continuous, practical and sustainable to truly achieve the purpose of English listening comprehensive ability improvement. Secondly, the students will realize that if you want to have a level harvest, they must make corresponding pay, and cannot just rely on classroom learning time. In daily life, combine with practice, and the cultivation of English listening is affected by aspects of reasons, such as English knowledge base, learning method, cognitive perspective, and individual intelligence. Find a suitable learning method, and quickly and effectively improve English listening ability.

\section{Deal with several relations}

\section{A. Deal with the relationship of listening materials and textbooks}

In oral English daily practice, reading text articles or related materials, make sure the pronunciation of each word, meaning and related phrases collocation, usage, etc.; On this basis, try to transfer reading vocabulary to listening vocabulary. Getting familiar with words formation, understand pronunciation, fixed collocation and pragmatic context, thus when doing listening practice, it is easier to understand, and after some time, English listening ability will have corresponding ascension. 


\section{B. Deal with the relationship between inside class and outside class}

Effective learning time should be grasped in class. Listen to the teacher's explanation, complete corresponding class listening task, and record confusing knowledge points in class for answers by consulting teachers in the end of the class; Classroom study and practice are short and limited after all, so students should arrange their spare time after class. Combing their actual level, make corresponding listening exercises, review and consolidate the learning content, and make the next lesson preparation; In addition to independent listening exercises, communicate as far as possible in the spare time with the surrounding classmates or teachers, remove doubts, and promote their English listening skills; they can also participate in some English activities to test their English listening and oral English ability.

\section{Deal with the relationship between English learning and listening ability cultivation}

To learn a language, a lot of knowledge needs to be learnt. In the process of English learning, we need to learn vocabulary, syntax, pragmatics, reading, listening, writing, oral expression and so on, and there is interrelated and complementary relationship between various learning contents. For students, to deal with the relationship between learning content and listening is to facilitate better English listening ability and level improvement.

First, deal with the relationship between reading and listening because in the process of English learning, reading vocabulary is usually larger than listening vocabulary, and the repeat rate between them is high, so the author thinks that, while the students can deal with the relationship between reading and listening, strengthen English reading materials, the corresponding vocabulary can produce subtle influence, and promote English listening level ascension.

Second, deal with the relationship between listening and pronunciation. Mastering a large vocabulary is the foundation of English listening ability training of course, but ensures that the mastered pronunciation of words is right, because if the student learns wrong pronunciation, no matter how many vocabulary they can master, in the process of listening, they cannot identify the contents of the listening material. This completely cannot cultivate listening ability, but affects the English learning ability of students in other aspects; the author suggests that students must develop good habits of pronunciation, strive for standard pronunciation, and accurately identify the correct words pronunciation so as to correctly understand the theme meaning expressed by the listening material.

Then deal with the relationship between listening and speaking. Listening and speaking have close relationship between each other. While practicing listening, at the same time also pay attention to the practice of oral English, because correct expression can help students get familiar English listening environment, help students to adapt to the context in listening comprehension, and develop 
their English listening ability; Finally deal with the relationship between listening and reading. At this point, the students have to make clear the difference between reading aloud and reading books. Reading books is to enrich the vocabulary, while reading aloud is an auxiliary practice in oral practice. And the process of reading aloud is the English lexical, syntactic internalization process. Through reading aloud, the abstract English characters are converted to vivid sentence structure, which deepens students' understanding and memory, thereby save time and improve memory efficiency and have the effect of smooth communication.

\section{Cultivate strong learning will quality}

English listening practice is of continuity, because human brain has an uneven forgotten laws, first fast then slow, a lot than a little, but after a certain time, it will gradually slow down, or even keep constant; So students must learn to have regular review and consolidation of the content in English knowledge learning to ensure that the knowledge no longer lost. The decisive factor influencing whether students can insist for a long time to review is that if the character is strong or weak; on this basis, the author puts forward some suggestions for cultivating English listening ability of from the perspective of students:

\section{A. Actively cultivate interest to improve English listening ability}

Interest is the best teacher. For students whose English learning ability is relatively weak, they need more to cultivate the interest of learning English. If not improve interest in English learning, English listening practice for a long time will only make the students more painful without fruits, and it will let students produce a kind of bored psychology; So the author thinks that arousing students' interest in listening comprehension is important so that the students can be actively involved in English listening practice, which has better effect than forcing the students to complete learning tasks.

\section{B. Make learning plan and avoid falling by the wayside}

English listening process is very long, and many students lack of willpower to stick. In addition to cooperate with the teacher in the classroom to complete basic tasks, it's hard to insist on the habit of listening after class; The author suggests that students work out a suitable learning plan, combined with their own level, ability and time, and avoid listening practice stop caused by lack of perseverance by the wayside; The content of the plan can be set as: do listening exercises every day, and review once or twice of the previous listening content. If time is enough, make preheated practice plan of next practice. Constantly improve their listening ability, and expand the scope of listening practice constantly to form a virtuous cycle. 


\section{Enhance self-confidence}

English listening practice is generally from easy to difficult, and students feel easy in the first place. Their learning enthusiasm is very strong and they have much hope for the cultivation of listening ability and improvement. With more difficulties in later study, many students have no confidence to continue to hold on; In fact English listening exercise is a long-term process, and students need to have enough time and patience, and have strong willpower and enough confidence to insist, avoid disqualified, waste of time and energy, which will bring them losses.

\section{Realize interesting English listening with comprehensive utilization of a variety of ways}

In today's modern society of advanced scientific and technological level, there are many ways of English listening practice, such as the use of multimedia in class equipment combined with audio, video, images, which makes English classroom listening study rich and colorful. Students can browse related English listening class practice sites and listen to the radio or download online audio files. Students can practice listening anytime and anywhere. The author thinks that interesting listening practice can be preceded from three aspects:

\section{A. Train English listening ability in entertainment}

Laptops, tablet computers, mobile phones and other electronic equipment are everywhere in universities, and college students often watch movies and listen to music as entertainment activities; cultivate English listening ability in entertainment mainly refers to pick up English listening ability by watching English movies, listening to English music, or reading some English e-books if students like reading, etc. The more specific image language environment, the more cultivation of the students' language sense and context can be achieved.

\section{B. Understand western culture and humanistic amorous feelings}

There are few western culture and customs, etc. in English listening teaching, so students do not have very good understanding, and listening content is wide with changing subjects; the understanding of the listening material is based on the understanding of western cultural background, which can help students better cultivate the ability of English listening. Language learning should also be the study of culture, so in daily life, pay attention and understand some appropriate English national humanities customs, values, and social system and so on, to facilitate a better understanding of English listening materials.

\section{Participate in college English activities}

There are always a lot of clubs and activities in university, and college students also send out moisture vigorous breath. Participate in some activities, strengthen the communication with people, and expand the circle of friends to make more rich university life. There are usually English clubs, 
English corners or some English lectures in colleges and universities, and students can get involved combining their own interest, communicate with different classmates, study learning methods, and share practice experience, etc. These can play a supplementary role in English listening exercises.

\section{Conclusion}

English listening ability has a very important role in English learning and practical application. The cultivation and improvement of the ability must be valued; especially under the influence of enrollment expansion of colleges and universities, there is a rapid increase in the number of college students. Teachers' energy is in shortage, and there are often a teacher who give English courses classes to two or more classes, and teaching methods and examination system and so on are all not perfect, which requires students to have stronger learning initiative; But in learning, students should pay attention to communication with classmates and teachers, know about different learning methods, set up correct learning concept, form good habits and set up suitable learning method with perseverance to constantly improve their ability of English listening.

\section{Acknowledgement}

This paper belongs to the project: The Methods of Improving the Listening Comprehension Capability of College Students within the Framework of Constructionism ("Education Reforming Research Project of Xihua University",2013). It is also one work belonging to the key discipline of School of Foreign Languages and Culture, Xihua University, Project Number: XZD1907-09

\section{References}

[1] Sun Yu, Wang Tianhao. College students' English listening ability cultivation after enrollment expansion from the standpoint of students [J]. Journal of Jilin Institute of Education, 2008, (9): 6162.

[2] Du Zhimei. College students' English listening ability training strategy exploration [J]. Journal of Contemporary Research Review, 2015, (5): 102.

[3] Lin Na. The cultivation strategy analysis on college English listening ability [J]. Journal of Policy Analysis [J]. Hua Zhang, 2013, (21): 161. 